\title{
On Secularization, Rationalization, and Other Mystical Things: The Unfinished Work of Marx's Religious Criticism
}

\author{
Christopher J. Roberts
}

The field of cultural studies has emerged over the last few decades to become a primary locus of interdisciplinary ferment in today's university. As its modes of inquiry circulate across disciplines, there is one circuit that to this day remains notably blocked: namely, that linking cultural and religious studies. To begin to remedy this situation, this essay aims to convince scholars who study culture that religion is a primary mode of acculturation and that it is incumbent upon scholars to pursue an interdisciplinary dialogue concerning religion. While this has taken place between anthropology and religious studies - indeed, the former has been a key discursive source for the latter - the dialogue between religion departments and other sites of cultural studies is still in its infancy. To pursue this rapprochement, this essay revisits Marx's views of religion, on the suspicion that his inverse position in the two fields is among the primary reasons for this blockage.

In the field of religious studies, Weber and Durkheim have become privileged figures for defining the methods of analysis and the modes of interpretation with which scholars have approached religious phenomena. Although a figure of equal stature, Marx is rarely invoked in religious studies, but in cultural studies his work provides a virtually unrivaled orientating perspective. At first glance, this is as it should be: it would be difficult, and some might even say unfair, to approach Marx as a scholar of religion because, unlike these others, Marx's understanding of modern commerce and politics largely determined his conception of religion. As a result, Marx's interest focused primarily on the way that religious practices and idioms influence the perception - or, the misperception - of politico-economic phenomena. This has contributed to the received idea that Marx redescribed the former as mere effects of the latter. ${ }^{1}$ Perhaps because Marx is thought to have

Christopher J. Roberts is a Ph.D candidate in Religious Studies at the University of North Carolina at Chapel Hill. 
committed the sin of reductionism, ${ }^{2}$ many scholars studying religions reject a Marxist framework in favor of a Weberian or Durkheimian one.

Despite the rather diffuse attention that Marx paid to this topic, because religions are historical phenomena that affect every sphere of society, a theory that offers the most compelling account of historical processes and modern social dynamics would be of great service to their study. Furthermore, since religions were only of secondary interest to Marx, the argument that his concept of religion was flawed would constitute only a weak criticism of Marx's theories as a whole. Besides, like Marx, both Durkheim and Weber predicted a diminishing role for religions in modern societies, and also rejected the notion that the category of religion constitutes an ahistorical and universal datum. Hence, the marginal role Marx plays in religious studies as opposed to cultural studies cannot follow solely from the charge of reductionism. Once we factor out the fact that all three predicted an everdiminishing role for religions as societies modernize, might we find the means to restore a Marxist perspective on religion to these fields?

It might be that this is already happening to some degree. For example, a scholar of religion recently formulated the dilemma facing the field as a choice between playing the role of "critics" or "caretakers" (McCutcheon). Because the latter term implies that scholars should support or endorse religions as endangered phenomena, it now appears to be a residue of the "secularization hypothesis" that Weber proposed and Peter Berger refined (to the point, ultimately, of rejection). ${ }^{3}$ As the intensification of religious activity taking place in Africa, Asia, and North and South America attests, religion is hardly at risk of disappearing. However, if recent decades disprove the imminent and inevitable advance of secularization, this effervescence coincides with an ever-widening gap between the rich and the poor both intra- and internationally. ${ }^{4}$ While admittedly such a correlation between politicoeconomic conditions and religious participation need not denote causation, such trends should prompt a return to Marx's positions regarding the relationship between religions and political economy.

In support of this return, one could argue that while Marx certainly reduces religion by dismissing all claims regarding its otherworldly or supernatural origins and ends, this is not far from the agnostic position adopted by any contemporary scholar in a secular university. Furthermore, as prototypically human phenomena Marx took great interest in religions and has much to say about them. In fact, this paper will argue that the depiction of religion as an epiphenomenon is itself a secondary effect both of Marx's methodological premises and his rhetorical strategies. Several recent texts have underscored the role that religious tropes play in Marx's rhetorical practice. Whether we consider the analysis of Marx's prophetic and messianic figures in Derrida's Specters of Marx, or Marx's inversions of angels and saints in John Schad's Queer Fish: Christian Unreason from Darwin to Derrida, religiously-inflected language now seems a critical component of Marx's rhetorical success. To think otherwise and attempt to quarantine Marx's truth from his rhetoric, or treat his texts as if they were the neutral bearers of his theories embroils one in the myth of scientism. Even if we focus solely on these hypotheses, their material efficacy - far from treating religions as negligible - actually plays an important 
role in Marxist theory, especially in passages where Marx's analysis is more historiographical than theoretical.

This paper will thus pursue a series of questions. First, I offer a critique ofWeber's Protestant Ethic thesis as an explanation of the role played by religion in the development of capitalism. Then I turn to a few of Marx's analyses of religion, culminating in Marx's examination of the role of the Reformation in the process of primitive or primary capital accumulation (the theory of the origin of capitalism that Weber's thesis opposed.) As I trace the way that Marx recognized the real consequences of religions in their socio-historical contexts, I will excavate a Marxist perspective on religion that can contribute to the project of rethinking some of the basic premises that have constituted the fields of religious and cultural studies.

\section{The Weberian Paradigm and Religious Studies}

For the social sciences, cultural and religious studies, Peacock and Kirsch claim that Durkheim and Weber offer contrasting analytical paradigms premised on the comparison between traditional and modern societies: "[Durkheimains] often attribute to modern rites, symbols, or customs, dynamics and functions that apparently underlie primitive rites, symbols, or customs.... [Weberians] attempt to define the dimensions according to which modern patterns have evolved beyond the primitive patterns" (115). Although the problem of the continuity or discontinuity between such societies cannot be reduced to an either/or choice, certain phenomena lend themselves more readily to one description or the other. For example, in regards to material and commercial culture, or the development of capitalism in general, discontinuity seems more the case, while in matters of religion, where tradition often plays an important role, one might make a case for continuity. As opposed to the liberal meliorism and ethnocentric evolutionism of early Victorian anthropologists such as E. B. Tylor and James Frazer, who assumed that the Enlightenment and the rise of science clearly separated the modernizing West from the rest of the world, the Durkheimian emphasis on the continuity between primitive and modern societies affords many opportunities to critically examine contemporary conditions. Such is the case with Bellah's notion of civil religion, ${ }^{5}$ for example, which can underscore the jingoistic nationalism it often foments as well as the connotations of xenophobic tribalism evoked by "One nation under God."

Yet the shadow Weber casts is longer. The immense scope of his analyses, his detailed typology of religious agents that complicates the clergy/laity distinction, and his bold comparative hypotheses offer a number of heuristic and hermeneutical tools to the scholar of religion. Moreover, religion for Weber is a focal factor of socio-historical development, since one consequence of his social nominalism is that the role of the individual agent and her motivations are of primary importance. It is no wonder, then, that Weber has informed so many of the great works that address the role of religious phenomena in the modern world.

There is another reason as well, perhaps one that follows more from the historical reception of Weber's work. In a way similar to Weber's Protestant Ethic thesis, which accords a prominent role to the Reformation as a liberation of individual religious and economic energies, the triumphalist narrative of American 
exceptionalism describes the formation of American society in similar terms. In its religious variant, this narrative hails the Constitution's Disestablishment Clause as an unprecedented breakthrough, ${ }^{6}$ one that made America a country where, paradoxically yet almost naturally, Protestants will flourish while adherents of other religions will flounder until they adopt Protestant tactics of religious reproduction like economic individualism and anti-clerical attitudes. As theorists often feel a moral imperative to employ a paradigm that resembles the self-conception of the religious practitioners they analyze, to do justice to the self-conception of their native informants scholars all too often adopt narrative frameworks that pivot on the success or failure of individual liberation or salvation. This kind of fairness, however, comes at a cost: when scholars so closely approximate the worldview of their objects of scrutiny, they effectively defuse the possibility of critique. Thus, in a kind of historical irony, Weber (and his emphasis on the discontinuity between modern, secular societies and more traditional, religious ones) predominates despite the fact that Bellah's Durkheimian notion of civil religion is so descriptive of the American form of patriotic self-regard. The irony consists precisely in the fact that Weber's hypotheses of rationalization and secularization have come to serve as fundamental myths in American civil religion. That a scientific hypothesis should come to serve as a religious myth should come as no surprise, since any putatively secular cultural artifact, be it an image, a narrative or a theory, is subject to this type of dialectical reversal.

This is not to say that Weber's predominance is solely the function of ideology or prejudice. Nonetheless, however appealing his work is to scholars of religion and culture, I would argue that Weber's hypotheses concerning the role of religion - Protestantism and Calvinism in particular - in the genesis of capitalism, while an interesting contribution, can serve as a complication but not as a replacement of Marx's account. After examining a few elements of Weber's Protestant Ethic thesis, I will then return to Marx's account of the secularization of church property in the English Reformation that precipitated the dispossession of the peasantry and created the preconditions for further capitalist development. After clarifying Marx's positions regarding religion's relations to the ideological superstructure of society, I will explain why only a myth stands in the way of utilizing Marxist resources for the cultural study of religion, especially as they attempt to describe the historical development of secular, capitalist societies and the role of religions within them.

\section{The Protestant Ethic Thesis}

Of Weber's thesis, there is no general agreement about its precise premises or scope. It is clear, however, that in explaining the genesis of capitalism not only as a system but as a culture or "spirit," Weber took aim at Sombart as well as the Marxists of his day. The view among them was a form of economic determinism that discounted the role of individual agents in the processes of socio-historical development. Against this, Weber proposed that "[o]ne of the fundamental elements of the spirit of modern capitalism, and not only of that but of all modern culture: rational conduct on the basis of the idea of the calling, was born - that is what this discussion has sought to demonstrate - from the spirit of Christian asceticism" (180). Weber's emphasis falls on several factors in complex articulation, including 
subjectivity, motivation and rationality. The ascetic elements in the calling allowed the scope of production to exceed traditional limits of need, and since it tended to minimize consumption at the same time that it maximized production, promoted the reinvestment of surplus production into the production process itself. In effect, this asceticism provided the values that motivated the protestant entrepreneur who developed capitalism as we have come to know it.

In addition to the organic metaphor of birth cited above, Weber also employs figures that emphasize the transposition of elements and the transgression of received limits. In reference to the specifically Protestant form of Christian asceticism, the calling, Weber concludes: "The Puritan wanted to work in a calling; we are forced to do so. For when asceticism was carried out of monastic cells into everyday life, and began to dominate worldly morality, it did its part in building the tremendous cosmos of the modern economic order" (181). While asceticism "did its part," we get little sense that other conditions were on hand to permit the building to proceed. That is, in order to emphasize the role of this asceticism, Weber has to take for granted other elements necessary to the development of capitalism. Since these elements have a history as well, here we encounter a more or less arbitrary historical demarcation regarding the real or true inaugural moment of capitalism.

Of course, to draw such a demarcation one must define the phenomenon at issue, which Weber insists is "the rational capitalistic organization of (formally) free labor" (21). Since Weber believes that the amoral and opportunistic "entrepreneur, the capitalistic adventurer, has existed everywhere" (20), the catalytic factors at first appear to be the elements of predictability and calculability entailed by the rationalization of economic practices. Yet Weber later concedes that another element is also a necessary precondition: "[e]xact calculation - the basis of everything else - is only possible on a basis of free labour" (22). Thus, for the emergence of the rational allocation and employment of resources, which Weber along with neoliberal enthusiasts insist the market best achieves, laborers must be reduced from the status of agents involved in production to resources or factors of production. Though Marx treats this in depth, Weber does not analyze this fundamental shift, and only treats the result, "(formally) free labor," as a given, initial condition.

Here we touch on a choice of nomenclature no less arbitrary than the historical demarcation - in fact, the two are fundamentally related. Weber puts "formally" into parentheses, I believe, because intellectual honesty compels him to acknowledge that this freedom was hardly a liberation in the eyes of the laborers. While it "freed" labor for capitalist production, this liberation came at the cost of great suffering on the part of the peasants whose customary way of life was lost forever. As we will see, because Marx directly addresses this process in terms of primitive accumulation, Weber's ambivalence seems to acknowledge Marx's contribution even as he attempts to minimize it. Although these are theoretical issues of great complexity, we can account briefly for this sleight of hand.

To accentuate the role of asceticism and the Protestant ethic in the genesis of rational capitalistic enterprise, Weber must discount the more objective or material factors that produced these conditions. This means that to avoid acknowledging the emergence of free labor as a catalytic factor, and thus the brutal self-interest and 
power involved in this expropriation, Weber has to treat it as a given, indeed as capitalism's natural resource. Although, as Marx insists in Capital, "In actual history, it is a notorious fact that conquest, enslavement, robbery, murder, in short, force, play the greatest part" (874), once labor is free, the focus can shift from force to motivation, though this too will be cleansed of the threats of destitution, violence, and literal starvation that serve as the perennial means of motivating free labor.

Once the situation has been trimmed in this way of all irrational elements, the question of motivation looms large because, as Weber makes clear, "traditionalism" (59) becomes the main obstacle, particularly in the sense that workers traditionally resisted and continue to resist the rigors of rationalized, disciplined production, which continues in Taylorism, Fordism and Toyotaism. ${ }^{7}$ Viewed through the interpretive lens of the Protestant sense of a calling or vocation as divinely sanctioned labor, Weber regards worker recalcitrance not as a rational preference for other values, such as free time with friends and family, or independent leisure and study (which Weber himself was fortunate enough to enjoy), but as an irrational resistance to earning more wages. Hence, to those workers who lacked a sense of vocation, for some literally unaccountable reason, "The opportunity of earning more was less attractive than that of working less" (60). This leads to the perversity of a negatively sloped labor supply curve, where "the worker reacted to the increase [of piece-rates] not by increasing but by decreasing the amount of his work" (59).

It is a matter of significant irony, then, that Weber's sharpest departure from Marx is also the origin of some of the troubling aspects of the Weberian hegemony in the study of religion. Beyond the facile equation of American geopolitical success with Protestantism and its individualism and work ethic, the Weberian tends to assume the essential rationality of capitalist social and economic formations, or at least, as Peacock and Kirsch suggest, capitalism's status as an unequivocal advance in the rationalization of social life over more primitive arrangements ${ }^{8}$ Once the rationality of the modern capitalist system has been assumed, one can retrospectively claim that the primary obstacle to the development of capitalism was the backwardness, traditionalism, or basic irrationality of pre- and non-Protestant laborers whose refusal to work more despite increased wages was due not to the lack of consumer goods available on which to spend their wages, or the understandable desire to enjoy leisure time, but a lack of motivation. By describing the laborer's resistance to the bridle of factory discipline as "stubborn" and "backward" (60), the Weberian paradigm leads to the view that humans are traditionally and/or naturally stricken with lassitude unless informed by appropriate values and coerced with adequate incentives. Unfortunately, this shares much with the implicit picture of human nature that allows such figures as Charles Murray, George Gilder, and Newt Gingrich to vilify the poor for their poverty and defuse criticism of systemic economic inequalities by explaining their plight as the inevitable consequence of a flawed character. By taking a Marxist view according to which human labor is the most fundamental means of self-realization and freedom, ${ }^{9}$ scholars of religion and culture can step outside this post-lapsarian prejudice against labor, which in its present form is itself both a consequence and a legitimation of capitalist relations of production.

Despite Weber's ambivalence about the development of capitalism voiced at the 
end of the Protestant Ethic, such nuances rarely travel as far as the triumphalist correlation of the Protestant articulation of asceticism as a calling, rationalization, and capitalist success. Furthermore, as foreshadowed by Weber's sense that working-class fragmentation in the form of free labor is required for the rational deployment of resources, in his General Economic History "Weber treats [the model of the laissezfaire capitalist economy] as an ideal type" (Collins 89). The economy as a machine programmed to produce ideal equilibria retains an appeal in sharp contrast to Marx's arguments in the 1844 Manuscripts that, although there are indeed interdependent relationships between the factors of production, the system's tendency is not towards equilibria but towards inevitable crises and suffering. These insights have not traveled as far as neoliberal dogma, however, and the idea of the free market translates all too easily onto the American religious terrain by way of the Disestablishment Clause of the Constitution. This has allowed for the migration of rational choice theory from economics and political science into religious studies as another front of an interdisciplinary movement originated by Nobel-laureate Gary Becker. ${ }^{10}$

Just as Weber meant his Protestant Ethic to complement and correct the flatly materialistic trend of quasi-Marxist economic determinism, scholars of religion now need to correct a one-sided reception of Weber's theses, restoring the means to question the ersatz rationality projected onto social relations as well as the role played by religion in class struggles. In true dialectical fashion, Weber's demythologizing narratives of rationalization and secularization have produced their own myths, the most prevalent of which are the myths of the "end of ideology" and the "iron cage of the status quo." These myths degenerate into the type of dogmas that mark the most ossified aspects of religious phenomena. Besides constituting a capitulation to the Freudian death-drive constantly at work in discourses of every kind, such narratives obscure the very real tensions - such as those between labor and capital, sustainability and productivity, equality and accumulation - that beset the capitalist mode of production. We will now turn to Marx's account of religion's role in the development of capitalism, and show why it provides a more compelling account of the process, even if it is less flattering to religion than Weber's.

\section{Marx and Religion as Palliative}

The most infamous of Marx's statements regarding religion occurs in his critique of Hegel's Philosophy of Right, where Marx claims that "[r]eligion is the sigh of the oppressed creature, the heart [or sentiment] of a heartless world, and the soul of soulless conditions. It is the opium of the people" (12). According to this metaphor, religion is a narcotic or palliative that treats the symptom but leaves the disease (alienation and exploitative relations of production) intact. Marx continues, "The abolition of religion as the illusory happiness of men, is a demand for their real happiness. The call to abandon their illusions about their condition is a call to abandon a condition which requires illusions" (12). Since unjust relations of production require and produce illusions, religion here is a secondary effect of exploitation. According to this passage, one might say that so long as the capitalist mode of production persists, so will religion, both as exploitation's symptom and, more positively, its relatively harmless solace. At any rate, the abolition of religion 
will not cause social justice, but only demand it.

Yet this implicit temporal framework also seems to make the abolition a precondition of the revolution. Marx thus indicates the necessity of an interregnum between religion's abolition and the satisfaction of real happiness - namely, class justice. This is a consequence of Marx's conviction that he was living in such an interregnum, since Feuerbach had finished the critique of religion by tracing religious claims about the divinity back to their origin as projections of human ideals and desires. Hence, Marx's entire sense of religion is predicated on the notion that, despite the dubious status of its narratives and truth-claims, religion answers to human needs, drives and desires that are themselves all too real. The secularization was inevitable, and already begun.

Because Marx states in many places that the proletariat itself has to develop in terms of number and cohesion before it will be ready to take control of the forces of production and reorganize the relations of production according to egalitarian principles, does it follow that one must begrudge the laboring masses whatever soporific effects their religions can provide? The answer to this question depends upon how one answers two others. First, given the dispersion of the proletariat along a continuum of suffering from near-absolute abjection to marginal deprivation and alienation, how might the relevance of religion differ across this spectrum? Second, in specific social and historical contexts, do we see religion serving only as a solace but also as a diagnosis? In light of these questions, a Marxist treatment of religion would involve an assessment more strategic than categorical, since in history religions have encrypted class struggle in various codes, and a recovery of these traces of revolutionary potential can transform the function of religions in today's societies.

A comprehensive survey of the catalytic effects of religious practices and idioms is not possible here, but one can suggest the range both in historical and geo-political terms. We find the figure of Christ's death playing a role in the explanation of the importance of union radicalism in Gilded Age America, ${ }^{11}$ even as a history of Protestant missionizing in Nicaragua contributed to the Miskito tribe's rejection of the social justice agenda of Catholic liberation theology, leading to the long civil war that decimated the country, with US help. ${ }^{12}$ In the history of colonialism, biblical exegesis informed lessons meant to refashion indigenous populations as wage-laborers, ${ }^{13}$ even as African-Americans translated narratives such as the liberation of the Hebrews from Egypt in ways that gave voice to their demands for emancipation. ${ }^{14}$

Religions in these examples are used for and against social justice movements, both as an overt instrument as well as a veil to deny the reality of any opposition or struggle. Despite the variety of ends served, this makes clear that religions are not merely epiphenomena: religions are polyvalent, multi-use instruments in the class struggle, ideological weapons of oppression as well as shared idioms in the struggle for class justice. If we take Bourdieu's treatment of art as an analogy, religion too is a form of cultural capital. It can serve elite interests when dominant tastes and interpretations privilege its formal aspects at the expense of message or content. That is, when the formal aspects of religion (the subjection to authoritative higher beings, the construction of a divinely sanctioned social order, the inculcation of dogmatic truth claims, the employment of theodicy as a means to justify inequality and suffering, etc.) gain 
prevalence over ethico-political content, the reactionary propensities of religious phenomena come to the fore. The heterogeneous contents, ${ }^{15}$ by contrast, cannot be reduced to simple egalitarianism, to be sure, but nevertheless constitute a powerful source of material and means for historical interpretation and contemporary action. Especially for the most destitute, religion is often the only cultural capital readily available to them, and thus becomes their primary heuristic device for confronting the world-historical significance of exploitation and suffering, as well as excavating latent possibilities of liberation and redemption.

\section{Religion and the Base/Superstructure Dichotomy}

While religion played a prominent role in politico-economic struggles in diverse contexts, Marx did not spend much effort engaging in specifically religious arguments. Although generally taken to indicate the virulent atheism of Marxist theory, his claim that religion is "the opium of the people" could also suggest that Marx's view of religion is in fact rather benign, a suggestion whose validity depends on the contention that, for Marx, the real battleground for social justice lies elsewhere. This diminished role for religion stems from Marx's belief that, in order to understand how society functions, we must see it not as a whole determined by an Idea or an Epoch, as with the Hegelians, but as a heterogeneous system divided into classes, and also into a base and a superstructure. As Raymond Williams suggests, the base/superstructure dichotomy is the analogue of the Marxist "proposition that social being determines consciousness" (3). In the base we find the forces and relations of production, or the material aspects of the processes by which capitalist accumulation reproduces itself. The superstructure, on the other hand, consists of the spheres of law, morality, religion, etc., each producing ideological justifications and rationalizations that attempt to suture or at least disguise the ineradicable contradictions between the relations and forces of production in the base.

Because Marx attributes the greatest historical potency to practices and not products of abstracted consciousness, the base/superstructure distinction also seems analogous to the division between mental and manual labor. To posit religion as purely superstructural and ideological, Marx utilizes a Protestant and Enlightenment concept of religion, according to which its sole function is to provide believers with a coherent explanation of the world, explanations that are usually produced by the clergy and consumed by the laity. This is a view shared by the scholars of religion who embrace rational choice theory, leaving little room for the horizontal development of religious capital as workers engage a capital-determined world with religious-based heuristic and rhetorical tools.

Just as scholars of cultural studies have had to climb down from a rarefied, Arnoldian notion of culture to reach the level of quotidian cultural practices, scholars of religion are now criticizing this view of religion as a purely theoretical activity, claiming that it is both over-intellectualized and elitist. Building on the dyad of "encoding/decoding" developed in the work of Stuart Hall and the Birmingham school of cultural studies, if one assumes that there is a necessary translation between institutions, their discursive production, and lived experience, then the lived religious experience of the laity is fashioned by the laity itself as it engages in 
a variety of activities, only some of which are ostensibly religious, though all are informed by theory to some degree and all are, ultimately, practices. In this way, one can begin to take into account the counter-practices with which the laity often contests the meanings asserted by the clergy. Furthermore, with religious practitioners engaged in community-building labor both mental (transmitting and contesting dogma, narrating the collective memory of the community, etc.) and manual (constructing cathedrals, monasteries, convents, orphanages, soup kitchens, food banks, etc.), a depiction of religion as a purely superstructural phenomenon, an ideology producing false-consciousness, is much too limited. In fact, at great stake in the struggle is often whether religious demands for justice are only to be realized in some other world or in the here and now by radical social reconstruction - that is, whether religion is rightly basic or merely superstructural. With religions as multiplex and heterogeneous phenomena in which a cross-section of all classes participate, one cannot easily shunt them to one side of the labor/capital or base/superstructure divide.

Why then does Marx himself keep religion contained within the superstructure? In true dialectical fashion, this apparent abstraction combines with a kind of critical privilege. Perhaps religion's prominent role in Marx's critical project derives from his belief that "[r]eligion is the general theory of this world, its encyclopedic compendium, its logic in popular form, its spiritual point d'honneur, its enthusiasm, its moral sanction, its solemn complement, its general basis of consolation and justification" ("Critique of Hegel" 11). Indeed, Marx repeatedly uses religion as the first term in analogies whose second term is the false appearance of one of the putatively rational social relations under capitalism, as when he states that "primitive accumulation plays approximately the same role in political economy as original sin does in theology" (Capital 873).

A further explanation is that Marx is above all a realist, and in his lifetime the intellectual, superstructural modes of religion tended to prevail. In other words, Marx's social being determined his consciousness. Marx was a child of the Enlightenment, and as such he took much from a Protestant iconoclastic rhetoric and turned it, not against other religions, as the Protestants did, but against society in its contemporary form. Religion, then, to Marx, was the paradigmatic but also weakest element of the superstructure, the one most readily criticized in order to reveal, pars pro toto, the ideological nature of the superstructure - and hence capitalist society - as a whole. In this light, in order for religion to function as a metonym for the ideological nature of the capitalist system, it is important for religion to remain firmly within the superstructure.

However, here we need a more dialectical view, one which is provided by looking at religious phenomena in Maussian terms as "total social facts." This in fact closely resembles Marxist analysis, in that one recognizes not only that "each of the special systems is only a part of the whole social system," but also "the supreme fact that they form a system" (qtd. in Goffman 66). In this light, religions, in making total claims about the world and providing the means for people to engage and contest that world, subvert the synechdochic/metonymic relation of part to whole. ${ }^{16}$ As in the paradox of the set of all sets, religions are parts of society that simultaneously claim to address or even comprise the whole, not only of society, but of nature as well. 
The view that religions and other elements of the superstructure are determined effects of a determining base seems to be a serious flaw in the Marxist framework. Yet Williams suggests ways to salvage this schema. By shifting from a view of determination that entails a fixed and mechanical expression to one where determination involves defining constraints and exerting pressures that delimit a finite set of possibilities, we can both account for the sense of freedom that superstructural phenomena often provide at the same time that we understand why superstructural liberation recalls Gramscian hegemony, in that it is predicated on leaving the base understood in the largest sense as the reproduction of capitalist society as a class society - uncontested. ${ }^{17}$ In just this way, "On the Jewish Question," for example, is not an essay whose primary target is religion per se, but rather state religion's articulation as civil religion. In this essay Marx rejects the ostensible liberation of the state from religion, and the palliative of religious freedom, as a mere semblance of real liberation, which, if it is to have any reality at all, will not only be religious and political but also economic. Religious liberation within the state is comparatively easy, since it involves an abstraction from social inequality and has in fact already taken place "ideally" - for, of course, we are all equal in the eyes of the gods. In regards to Jewish liberation, then, Marx saw that overcoming oppression did not consist simply in the surpassing of state religion for this too easily feeds into a religion of the state. Civil religion worships the state as an entity to which all loyalty is due because it supposedly guarantees, among other things, religious freedom, yet this same entity plays a critical role in constructing firewalls that keep the hunger for liberation from taking the inequities of civil society as its object.

\section{Marx on Religion in History}

Having salvaged a Marxist view of religious phenomena, we can examine more closely Marx's treatment of religions in specific historical contexts. We must consider how Marx uses religion in his texts, in ways already discussed (as the clearest example of a super-structural phenomenon, or as the paradigmatic form of ideology), but also as an inflecting filter of socio-historical forces. In doing so, we will see that Marx himself recognizes religion's context-dependent role in the production and reproduction of social relations. In doing this I want to suggest that Marx's ambivalence about religion bifurcates along the lines of two divergent textual strategies: that of historiography and systematic theory.

As noted above, Marx often employs religious idioms when constructing analogies illustrating the false interpretations of prevailing politico-economic conditions. Because these analogies criticize contemporary phenomena, they generally remain within the synchronic perspective of capitalism as a regnant mode of production. In these synchronic terms, Marx describes religion as totally determined by the dominant mode of production, and thus wholly incapable of mounting an offensive against its hegemony. By contrast, when the pre-history or genesis of capitalism itself is in question, Marx's analysis is more complex, and often strikes a different chord.

The first example I cite is Marx's account in the first volume of Capital of the period of "primitive accumulation" in sixteenth-century England. One of the consequences of the Reformation movements on the European mainland was Henry 
VIII's secularization of England's monasteries and other church properties. As Marx described it, "[t]he process of forcible expropriation of the people received a new and terrible impulse in the sixteenth century of the Reformation, and the consequent colossal spoliation of church property" (881). Marx thus links secularization causally to primitive accumulation. Secularization and its correlatives, the processes of commons enclosure and estate engrossment, involved not only the reallocation of land and rights, for " $[\mathrm{t}]$ he property of the church formed the religious bulwark of the old conditions of landed property. With its fall, these conditions could no longer maintain their existence" (881). Serving as an impetus and example, secularization had a profound effect on both the peasants and the landed gentry, but was merely a part of a greater transformation - not only a land grab but also an expropriation that moved a great way towards producing Weber's formally free workers, a class of people with no other resource to sell than their living labor.

Because the enclosure of common lands and the engrossment of large estates entailed the expulsion of great masses of peasants, this primitive capital accumulation instantiated the naked facts of class struggle, since the ruling class's accumulation involved not a simple appropriation of a natural resource, but the expropriation of the peasantry, producing a veritable army of the unemployed ready for proletarianization. Marx suggests there is a strong religious and political connection between the monastery expropriations and the land enclosures: in effect, the religious upheaval produced socio-economic effects by forming a correlation, imparting an impetus, and providing a rationale. Even if one insists that the monastery expropriations were economic (basic) events facilitated by a religious (superstructural) justification, this religious aspect added greatly to the velocity of the process, thus producing specific effects due to the flood of destitute peasants too suddenly uprooted for the contemporary level of productive forces to absorb. In the same way, the fact that the uprooted peasants had only customary and not legally binding claims to the land illustrates the way that superstructural phenomena (the common law, legal reasoning, juridical institutions) produce effects in the base, thus putting the validity of a starkly contrastive reading of this dichotomy into question. Even if one argues that religious phenomena like the Reformation are only effects of socio-economic forces, as Marx seems to do,$^{18}$ it is difficult to maintain that religion as an element of the superstructure is nothing but a reflection pure and simple, and cannot in turn affect the socio-economic base. Religion does not reinvent the world in its image, but it quickens and retards various processes in that world in context-dependent ways.

The final historical instance I will discuss examines religion not in terms of the genesis of capitalism, but as a factor in the genesis of society as a whole. At one point in The German Ideology Marx and Engels, while discussing the origins of society, suggest that it is correlated with the origin of the social division of labor, which must be distinguished from the division of labor that arises from merely natural sexual and physiological differences. By contrast with these:

Division of labour only becomes truly such from the moment when a division of material and mental labour appears. (The first form of ideologists, priests, is concurrent.) From this moment onwards consciousness can really flatter itself that it is some- 
thing other than consciousness of existing practice, that it really represents something without representing something real; from now on consciousness is in a position to emancipate itself from the world and to proceed to the formation of 'pure' theory, theology, philosophy, ethics, etc (51-2).

Marx and Engels present the priesthood as present at the origin of the social division of labor. With the distinction between manual and mental labor, properly religious roles, as perhaps the most definitive and socially recognizable effects of this division, play a pivotal part in generating a permanent qualitative division of labor that will have momentous consequences. By making religion as a separate institution coeval with the social division of labor, it is virtually impossible to hold that religion is solely superstructural and thus only an effect of social forces, because at minimum religion is responsible for reproducing obfuscating distinctions such as that between mental and manual labor. Religion in its present form, then, as the dialectical origin and effect of the division between mental and manual labor, helps account for the origin of our upside-down world, a semblance whose corrective - but often overstated - reversal is the dichotomy of base and superstructure.

In conclusion, this prominence of the base/superstructure dichotomy in Marx's work stems from two different approaches that he employed at different times. When Marx is interested in showing how the capitalist system hangs together as a disjointed, fractured, but incredibly dynamic whole, that is, from a synchronic perspective, the base/superstructure distinction helps to clarify the real determining priority of some social functions. Likewise, the synchronic perspective, which by definition excludes historical change in order to reveal a variety of regulated "transformations," necessarily presents religion as a superstructural reflection incapable of effecting change. By contrast, when Marx shifts to historical examinations, the diachronic role of religion in shaping society is impossible to deny.

\section{Marx and the "Criticism of Religion"}

If I have argued that Marx exhibited a great deal of complexity in his treatment of religion, I have thus far done nothing to shake the impression that he was opposed to it in general. The ambiguities we have examined so far only regard its degree of culpability - that is, whether it is a secondary, superstructural ideology or an insidious factor of exploitation in its own right. There remains, however, another degree of ambivalence for us to excavate.

Just before the "opium" passage quoted earlier, Marx states that "die Kritik der Religion ist die Voraussetzung aller Kritik" ("the criticism of religion is the premise of all criticism") ("Critique of Hegel” 11). There are three terms here that require elucidation: criticism, religion, and premise. To begin with the latter: in logic and rhetoric, a premise is the first term of a syllogism or the first proposition of an argument, which is usually meant to be a self-evident or obvious assertion to which one's interlocutor will readily assent. How curious for Marx to present a kind of criticism as a premise. If criticism requires a questioning and skeptical stance taken towards an erstwhile given, an attitude opposed to the self-evident status of all premises, criticism as premise becomes an anti-premise. Is Marx's critical project to reject on principle the rhetorical reliance on premises, this most traditional means of persuasion and consent? 
I believe not, for Marx was above all a historical thinker, and criticism is a term that has had an identifiable history. As Marx encountered it, criticism as a mode of discourse was an Enlightenment project, and the skeptical aspect of criticism was merely one stage on the way towards a greater goal. Kant's self-described critical philosophy attempted to establish the limits of knowledge in order to unmask the dogmas of reason that led Hume to contest them by rejecting notions such as subject and causality. Kant's theory that human knowledge of the world is constructed according to a priori conditions made the critical evaluation of premises and presuppositions more than a necessary step in the process of knowledge construction. Because knowledge of the world is an expression of human activity, criticism removes impediments to the exercise of this most essential form of human agency, making criticism tantamount to emancipation. Thus, many saw Kant's epistemological theory as directly relevant to political economy as well. In the next generation, the young Hegel was inspired by the French Revolution, though the elderly Hegel asserted that the only thing necessary for liberation is for us all to realize that the rationality of freedom was precisely what had been instituted by the modern nation state: in effect, freedom was to be won by coming to understand how free we already were, or at least, were already on the way to becoming. ${ }^{19}$ Even the Left Hegelians, rejecting this position, merely proposed alternative types of conversion or insight as means of achieving freedom. Thus, critical philosophy as Marx inherited it was an unfinished project threatened with ossification by decades of theoretical blinkers. Marx was the first critical philosopher to reject mental labor's privileged status and announce, in the eleventh "Theses on Feuerbach," "The philosophers have only interpreted the world, in various ways; the point is to change it" (109). With this, "criticism", derived from the Greek krinein ["to judge, to separate, to distinguish"], had traveled full circle: where once a critic abstained from practice in order to attain a more objective perspective, now a critic actively engaged in history as a socio-political agent, thus contributing to a communal project of emancipation.

As for the third term, I have already stated that Marx has an intellectual view of religion and explicitly employs iconoclastic rhetoric in many places, particularly in his analysis of commodity fetishism, by making false ideas analogous to idols wrshipped by the credulous. Furthermore, as an analyst of capitalism, Marx was decidedly Eurocentric; thus, when Marx speaks of religion, he does not use the plural, and I do not think that he had much else in mind than the European Christianity, Catholic or Protestant, which again and again seemed to side with elites in class struggles. ${ }^{20}$

A common feature of Enlightenment critics (and many Reformation theorists) is a disquiet regarding the frequent collusion between church and state. Of course, this was not always the case. As perhaps the first form of international coalition, the various world religions often developed as adversarial movements within the domain of existing state religions. This circumstance often provided their practitioners with a critical distance from the sovereign powers of the state as well as dominant social practices. Along these lines, Marx quotes Luther's rebuke of usurers for preying upon the poor with approval. ${ }^{21}$ Marx, then, could admire the religious when they challenged existing forms of exploitation, and the fact that it was 
often precisely a religious perspective that informed this challenge could not have been lost on him. In speaking of ideological institutions, then, it seems that Marx condemns in particular the religions that failed to maintain this distance from the state and capitulated entirely to power.

Finally, I want to examine a syntactic element of the sentence above, the possessive preposition "of" in the phrase "criticism of religion." One of the most effective critical methods that Marx learned from his predecessors was the strategic reversal, the substitution of effects for causes, actions for agents, and qualities for objects. A dialectical view of the phrase, then, would give us, "religion's criticism is the premise of all criticism." Though grammatically permissible, what, if anything, does this linguistic ambiguity reveal about Marx's relationship to religion?

There is a great deal of variation in Marx's positions, but an early letter to Ruge is widely considered to be his first programmatic statement of purpose, and in many ways it supports the genetive reversal that depicts Marx's project as consistent with religion's criticism, that is, with religions when they challenge exploitation:

Our motto must therefore be: Reform of consciousness not through dogmas, but through analyzing the mystical consciousness, the consciousness which is unclear to itself, whether it appears in religious or political form. Then it will transpire that the world has long been dreaming of something that it can acquire if only it becomes conscious of it. It will transpire that it is not a matter of drawing a great dividing line between past and future, but of carrying out the thoughts of the past. And finally, it will transpire that mankind begins no new work, but consciously accomplishes its old work.... It is a matter of confession, no more. To have its sins forgiven mankind has only to declare them to be what they really are (10).

While still cast in the quasi-religious language of theory ("reform of consciousness," "consciously," “confession," "declaration") and thus before Marx's turn to practice, from this passage one senses that he builds upon the prophetic, critical components of religion even as he criticizes religion's dogmatic ossifications. What Marx meant when he criticized religion, then, was European Christianity, aligned with the state and renouncing all critical distance, heliotropically turning towards wealth and power. What Marx explicitly criticized was less religion in the widest possible sense than specific religions performing certain functions. In this broader sense of religion, as not only the mournful sigh but also the rallying cry of oppressed masses, Marx's project is a continuation of its "old work," the quest for the amelioration of suffering and, ultimately, that "longest dream," equity for all.

The critique of Weber and the return to Marx that this essay has pursued should suggest that we are never more beset by a fixed, inflexible and unconscious narrative than when we insist that we are finished with or beyond religion. Every disenchantment dialectically conjures its own enchantment. As certain scholarly conceits regarding secularization and rationalization have come to seem so obvious that they are no longer questioned, scholars would do better to treat religions like the Greeks treated their myths, with a supple and inquisitive joy in re-presenting them and subjecting them to interrogation. Like myths, religions provoke thought, and accomplish more cultural work than just training people to parrot received 
ideas. Indeed, religions should not be merely objects of critique, for in history each has also been the source and stimulus of multiple modes of critical reflection. Although Marx is often misunderstood as the very voice of dogmatic atheism, his heterogeneous corpus borrows a great deal from religion. Therefore, it can only be to the benefit of scholars who would examine the role of religions in socio-cultural reproduction to excavate the thread of religious critique in the works of this critic of religion, as one step in helping us understand how his texts converted so many with their depictions of society, and how they continue to illuminate the function of religion and culture in the world today.

\section{Notes}

I would like to express my gratitude to this essay's two anonymous reviewers. Their critiques and suggestions were immensely helpful, and this essay was much improved as a result of their scholarly generosity.

${ }^{1}$ The problem scholars of religion have had with the determination of religion by politico-economic phenomena is a sense that any explicit relation had to be mechanical, one-way, and thus formulaic. Of course, such a view of determination was decisively complicated by Gramsci's notion of hegemony, with generations of scholars such as Raymond Williams, Stuart Hall, Fredric Jameson and Lawrence Grossberg exploring the complicated relationships between cultural spheres and the various modes of late capitalism. Since a fear of determinism now serves only to isolate the field of religious studies from related fields such as anthropology and cultural studies, the goals of this essay are, first, that scholars of religion will move beyond the cliches of determinism that make Marx taboo, and, second, that scholars of culture will begin to take religions seriously as primary modes of acculturation and storehouses of polyvalent cultural capital.

${ }^{2}$ Reductionism is the term that arose in religious studies to describe the position that religions have no content or phenomena that one cannot better describe in terms of socio-cultural or politico-economic phenomena. In some variants, reductionism designates the mechanical determination of religious by extra-religious phenomena commonly seen in "vulgar marxist" and ideological critiques.

${ }^{3}$ In The Sacred Canopy: Elements of a Sociological Theory of Religion, Berger brings Durkheim and Weber together in the central metaphor of the title: while religions as social projections once provided communities with an overarching framework and means of cohesion (Durkheim's social function of religion), Berger hypothesizes that, as societies modernize, this integrative function will shift from religion to science and other disenchanted institutions and discourses (Weber's rationalization and secularization as historical trends).

${ }^{4}$ The data is still coming in, but one illuminating report, "The Scorecard on Globalization 1980-2000: Twenty Years of Diminished Progress," can be found on the Center for Economy and Policy Research website at www.cepr.net.

${ }^{5}$ In his influential essay, "Civil Religion in America," and numerous other publications, Bellah adopted the Durkheimian position and argued convincingly that the putatively secular nation-state gradually became re-enchanted by means of discourses and rituals of civic pride, loyalty and patriotism. 
${ }^{6}$ For a self-consciously liberal work that still takes this narrative for granted, see Eck.

${ }^{7}$ On the persistence of working-class resistance in the form of customary holidays like Saint Monday, as well as the admonitions with which the clergy attempted to instill in workers a sense of time amenable to capitalist production, see Thompson.

${ }^{8}$ While an unquestionable advance in terms of productivity, the advance is equivocal in regards to other metrics, such as social justice, egalitarianism, ecological responsibility, and long-term sustainability.

${ }^{9}$ In the eighth "Theses on Feuerbach" we read: "Social life is essentially practical. All mysteries which mislead theory into mysticism find their rational solution in human practice and in the comprehension of this practice" (109).

${ }^{10}$ For a key development in this project, see Becker. Becker's acolytes in religious studies include such scholars as Rodney Stark, Roger Finke and Laurence Iannacone.

${ }^{11}$ From the Coast Seaman's Journal we read: "Christ taught that all men had souls and were therefore equal in the finality of things. For that He was put to death. But it was not for preaching the doctrine of a common equality before God that the Saviour suffered. The Powers have never objected to changing the conditions and relations of the future: it is the conditions and relations of today they object to altering. Christ was crucified because the doctrine of common equality hereafter, which He preached, led inevitably to the doctrine of common equality now. This is the essence of Christ's teaching" (quoted in Gutman 96).

12 " [A]s the Bible became part of the communication of Miskitu ethnic identity, it was not just a means of differentiating themselves from the Spanish. It was also an affirmation of allegiance towards the powerful Anglo domain, in which the Miskitu had embedded themselves when they converted to Christianity. It was this allegiance which led the Miskitus to side with the US in their covert war to topple the Sandinista government" (Hawley 338).

${ }^{13}$ The examples here are legion. The ethnographic work of Michael Taussig provides multiple South American examples. In terms of the history of Central and South America, "The Bible was read and interpreted according to colonial and occidental interests.... The biblical schema of the conquest by Joshua of the Canaanite people was applied to the conquest of the indigenous peoples. Indigenous religions were fought by using the prophetic tradition of opposition to idolatry.... Juan Gines de Sepulveda was ... easily able to utilize the Bible and occidental Christian thought in order to justify the most horrible genocide in the history of Christendom" (Richard 306).

14 "Christian slaves thus applied the Exodus story, whose end they knew, to their own experience of slavery.... Exodus functioned as an archetypal myth for the slaves.... By appropriating the story of Exodus as their own story, black Christians articulated their own sense of peoplehood. Exodus symbolized their common history and common destiny.... Exodus became dramatically real, especially in the songs and prayer meetings of the slaves, who reenacted the story as they shuffled in the ring dance they called 'the shout'" (Raboteau 84).

15 This heterogeneous content involves such disparate but interrelated phenomena as scripture and ritual, clerical codifications of worship and lay improvisation, cosmological models and ethical principles. Even within scripture, the legiti- 
macy of which often depends upon the semblance of homogeneity, one finds multiple strata of interpretation and redaction, as well as heterogeneous discursive modes, such as myths, priestly taxonomies, genealogies, and historical fragments.

${ }^{16}$ Williams suggests that the base is open to the same expansion: "Now when we talk of the base, and of primary productive forces, it matters very much whether we are referring, as in one degenerate form of this proposition became habitual, to primary production within the terms of capitalist economic relationships, or to the primary production of society itself, and of men themselves, material production and reproduction of real life. If we have the broad sense of productive forces, we look at the whole question of the base differently, and we are then less tempted to dismiss as superstructural, and in that sense as merely secondary, certain vital productive social forces, which are in the broad sense, from the beginning, basic" (6).

17 "We have to revalue 'determination' towards the setting of limits and the exertion of pressure, and away from a predicted, prefigured, and controlled content. We have to revalue 'superstructure' towards a related range of cultural practices, and away from a reflected, reproduced or specifically dependent content. And, crucially, we have to revalue 'the base' away from the notion of a fixed economic or technological abstraction, and towards the specific activities of men in real social and economic relationships, containing fundamental contradictions and variations and therefore always in a state of dynamic process" (Williams 6).

${ }^{18}$ In The German Ideology, Marx and Engels note how, if "theory, theology, philosophy, ethics comes into contradiction with the existing relations, this can only occur because existing social relations have come into contradiction with existing forces of production" (52). That is, a superstructural contradiction develops only when there is the necessary condition of a contradiction in the base.

${ }^{19}$ I do not want to make Hegel an ex post facto revolutionary, but the statement from his "Preface" to Elements of the Philosophy of Right - one translation of which reads "What is rational is actual; and what is actual is rational" (20) - suggests a debunking reading closely akin to Marx: to discover the rational, look not to the ideal but only to the real, although Marx certainly disputes Hegel's account of what the real in fact is. Thus, Hegel can be read as more anti-Kantian than pro-Prussian.

${ }^{20}$ Of the three major apostolic movements of the 12th and 13th centuries which championed poverty as a spiritual ideal (this is not meant to imply that these were precursors of Marxism, for the latter does not "advocate" poverty), one became coopted (the Franciscans) while two, the Waldensians and the Cathars, wound up on the wrong side of the Albigensian Crusade.

21 "[W]e hang the small thieves... Little thieves are put in the stocks, great thieves go flaunting in gold and silk... Therefore is there, on this earth, no greater enemy of man (after the devil) than a gripe-money, and usurer, for he wants to be God over all men" (Luther quoted in Capital 740). Remarkably, the sanctification of interest was a Franciscan project, meant, in part, to encourage charitable giving and increase monetary liquidity. From a stark dichotomy between charity and usury, Francis of Assisi helped develop the modern gradations between low-interest (fair or charitable) loans and exorbitant (predatory and illegal) usury. 


\section{Works Cited}

Becker, Gary. "A Theory of the Allocation of Time.” The Economic Journal 75.299 (Sept 1965): 493-517.

Bellah, Robert. "Civil Religion in America.” Daedalus 96 (Winter 1976): 1-21.

Berger, Peter L. The Sacred Canopy: Elements of a Sociological Theory of Religion. Garden City, NY: Anchor, 1969.

Bourdieu, Pierre. Distinction: A Social Critique of the Judgment of Taste. Trans. Richard Nice. Cambridge, Mass.: Harvard UP, 1984.

Collins, Randall. "Weber's Last Theory of Capitalism: A Systematization." The Sociology of Economic Life. Ed. Mark Granovetter and Richard Swedberg. Boulder, CO: Westview, 1992. 85-110.

Eck, Diana. A New Religious America: How a "Christian Country" Has Become the World's Most Religiously Diverse Nation. New York: HarperCollins, 2001.

Gofman, Alexander. "A Vague but Suggestive Concept: The 'Total Social Fact'." A Mauss Centennary. Oxford: Berghan, 1998. 63-70.

Gutman, Herbert G. "Protestantism and the American Labor Movement: The Christian Spirit in the Gilded Age." Work, Culture, \& Society in Industrializing America. New York: Vintage, 1977. 79-118.

Hawley, Susan. "Does God Speak Miskitu? The Bible and Ethnic Identity Among the Miskitu of Nicaragua." Ethnicity and the Bible. Ed. Mark G. Brett. Boston: Brill,2002.315-42.

Hegel, Georg Wilhelm Friedrich. Elements of the Philosophy of Right. Ed. Allen W. Wood. Trans. H. B. Nisbet. London: Oxford UP, 1991.

Marx, Karl. Capital. Ttrans. Ben Fowkes. Vol. 1. New York: Penguin, 1990.

- . "Contribution to the Critique of Hegel's Philosophy of Right: Introduction." The Marx-Engels Reader. Trans. T. B. Bottomore. Ed. Robert C. Tucker. New York: Norton, 1972. 11-23.

—. "Letter to Ruge." The Marx-Engels Reader. Trans. Ronald Rogowski. Ed. Robert Tucker. New York: Norton, 1972. 7-10.

—. "On the Jewish Question." The Marx-Engels Reader. Trans. T. B. Bottomore.Ed. Robert Tucker. New York: Norton, 1972. 24-51.

—. "Theses on Feuerbach." The Marx-Engels Reader. Trans. Friedrich Engels. Ed. Robert Tucker. New York: Norton, 1972c. 107-09.

Marx, Karl and Friedrich Engel. The German Ideology, Part One: With Selections from Parts Two and Three and Supplementary Texts. Trans. W. Lough, C. Dutt, and C.P. Magill.Ed. C. J.Arthur. New York: International Publishers, 1995.

McCutcheon, Russel T. Critics not Caretakers:Redescribing the Public Study of Religion. Albany: State U of New York P, 2001.

Peacock, James L. and A. Thomas Kirsch. The Human Direction: An Evolutionary Approach to Social and Cultural Anthropology. New York: Appleton, 1970.

Raboteau, Albert J. "African Americans, Exodus, and the American Israel." Religion and American Culture: A Reader. Ed. David G. Hackett. New York: Routledge, 1995. 73-88.

Richard, Pablo. "Biblical Interpretation from the Perspective of Indigenous 
Cultures of Latin America (Maya, Kunas, and Quechuas)." Ethnicity and the Bible. Ed. Mark G. Brett. Boston: Brill, 2002. 297-314.

Spiegel, Shalom. The Last Trial: On the Legends and Lore of the Command to Abraham to Offer Isaac as a Sacrifice: The Akedah. Trans. Judah Goldin. Woodstock, VT: Jewish Lights, 1993.

Thompson, E. P. “Time, Work-Discipline, and Industrial Capitalism." Past and Present 38 (Dec 1967): 56-97.

Weber, Max. The Protestant Ethic and the Spirit of Capitalism. Trans. Talcott Parsons. London: Routledge, 1992.

Williams, Raymond. "Base and Superstructure in Marxist Cultural Theory." New Left Review 81 (1973): 3-16. 